УДК

\title{
BODY AND SOUL: CONTROVERSIES OF AESTHETICS OF POSTMODERNISM IN POST-SOVIET SPACE
}

\section{Jüraté Landsbergyté-Becher}

\author{
orcid.org/0000-0003-2356-7264 \\ jurate128@yahoo.de \\ Doctor of Music Art (Musicology) \\ Research Fellow in Department of Music and Theater History Research, \\ Lithuanian Culture Research Institute
}

\begin{abstract}
The article discusses the latest discourse of Lithuanian literature and political reality with arisen aesthetical, ethical and historical conflicts. The interplay of the post-Sovietism still reflecting the Soviet interpretation of Empire and Lithuania as part of it and the interaction of postmodernism simulacra in M. Ivaškevičius "novel "The Greens" (2001) appears renewed because of the 2018 National Prize of literature awarded to the author. The novel awakes the series of deep wounds in the perception of post-war reality. The painful contradictions arise from the author's voluntaristic simplicity in playing with traumatic history and his lack of research experience in certain problematic areas, in other words, the writer's literary superficiality assumes a bullying style. The philosopher Jürate Baranova remembers in this context Sigmund Freud's idea about the infantility of writer as such. At present, this is particularly evident in Lithuania, when it becomes impossible to ignore history, reopened by the latest discoveries made by historians and archaeologists and by long hidden terrible testimonies of the partisan warfare. Therefore, this intersection of the three "post": post-Sovietism, postmodernism and scholarly research of the past is particularly painful for many people, but relevant and inevitable. Such works, as "The Greens", can only be understood in this context.
\end{abstract}

Key words: postmodernism, post-Sovietism, simulations, disinformation, context, corporality, anti-text.

In the space of new Lithuanian literature, the strange star of the past - the period of occupation originating from the post-Sovietism has lit up: literature on the interaction of postmodernism and postSovietism. This interaction is aesthetically confused, stuck in time, a reminder of still standing empty monstrosity with hollow windows, the Soviet warehouse - the ideological concept of simulations. The winds of the present global contexts blow through these holes. Moreover, the society simply has doubts about the use of its existence.

Aspects of interaction between postmodernism and post-Sovietism

Postmodernism is described by art philosophers as a particular decadent form of modernism, which has set itself the goals of showing "the global degradation" - the destructive transformation of the world, named capitalism. It is characterised by a confusion of values, also called the "carnival of simulacra" $[19$, p. 23], which is effective in purifying historical change, transformations of phenomena, decoding the role of marginal or reflexive layers in culture. Here a paradigm of aesthetics as creation of beauty changes. It can be replaced by blunt "ugliness", its motivation is chaotic, non-centered, and the form is fragmented into playful indiscreet gestures, "points of shame" or all interrupting intersections. Such concept of aesthetic transformations can very controversially disperse in the post-Soviet damaged space, where much of absurdity remains. Its duality and relativism regarding the past are overwhelming. The processes, which take place here, the postmodern actions in the post-Soviet space can be deservedly named as wars of aesthetics or absurd of absurdities [3] spinning in their antihistorical unethical interpretations. It is worth noting the features of fragmented post-Soviet space: painful points of the past, the post-traumatic psychology, and the chain of wounds of history. At this moment, the post-modernist "redeployment" of reality seems to be another form of Soviet hybrid war, demonstrating stylistic and transformational ingenuity. It can be said that the principles of postmodernism and post-Sovietism sometimes partially and sometimes completely overlap or are similar and often perfectly match each other. Such "duo" turns into a rotating energy spiral and pushing another "fractured time" dilemma of post-Sovietism into corporality, calling itself the aesthetics of postmodernism. 
Non-cognitive aggressiveness towards the past wakes up as a shadow of Self full of Ego (according to C. G. Jung) with reflections of the post-modernist literary style. One such example of the controversial "meeting" of the unforgettable Sovietism monster and postmodernism is the early work of Marius Ivaškevičius (born in 1973), the winner of National Prize in literature in 2018 for the novel "The Greens" (Tyto alba 2002, 6) written in 2001. Why do the postSoviet and postmodern malice discourses meet here? The first reproduction of reality in the novel is the "playful" concept of the already dead Soviet ideology, although it provides a basis for diversified postmodern simulacrum. This damaged political incompleteness is replete with actions of corporality and sexuality. The writer's fantasy in the form of the postmodern strain of emptiness floats into particular literary style and linguistic level.

Postmodern postulates particularly intersect with the post-war struggle for freedom, which they turn into absurdity, cut off from its semantic connotations. So both the language and the style experience a meaningful "verbal emptiness" or anti-text. It could be argued that space and time do not meet there. Lithuania, like many Eastern European states, is still not a good place for postmodernity with its simulacra to flourish; on the contrary, it is good for research full of non-diminished images of history. The phrase game in this zone becomes very strange, like a foreign matter. The purpose of the "game" is unclear. In his book, "Just Gaming", one of the founders of postmodernist philosophy Jean-François Lyotard comes to "maybe paradoxical conclusions that duties cannot be precisely defined, first of all, because a duty cannot be submitted for clarification. If it were possible, the duty/ (quasi-) duty would disappear. $<\ldots>$ Duty is the result of the law of "others" but not of "my" law... The ethical phrase for the duty's reference may be a sign of a commitment, which never acquires a specific form." $(11$, p. 86). By raising the phrase above the universal link into the privileged position on the differend, Lyotard risks making the differend unclear because there is no non-phrase. Silence, shouting, shrugging the shoulders - everything are just phrases.

Moreover, there is no first or last phrase because there is always a link between phrases. To say that there is nothing else but a phrase means saying that the phrase comes out from itself, i.e. it is the law by itself. However, there is a particular risk that this statement may become a limiting totalisation, contrary to the principle of enabling the differend to occur [10, p. 287]. This particular phraseological stagnation of the style, which stems in a totalising space, can be observed in Ivaškevičius's "The Greens", where is a lack of "heterogeneous state" or differend, or the basis of the idea of "some" minor seeking for help. The implied historical context necessary for the opening of thought associations vanishes with the emptiness. The push in times is hard for "The Greens" as a historical novel, where everything revolves around the documented reality. It could be said that the text here is "without the body" although the body here acts as the source of the text shifting it toward corporality, sexuality and non-motivated violence.

\section{"The Greens" and corporality}

The author declares his "non-communication zone" in the foreword for the book telling us that "all this is a huge fiction", however, by choosing a certain database of archival documents as a background for the action, he denies his choice. Then the problem is moved to a "postmodern game". It yet remains in a "dangerous zone" for literary language regarding the aesthetic slipping into totalisation: for example, creating "nonsenses" by repeating words, signs of emptiness, boredom, non-acting, waiting for the corporality to speak out, regaining a strange location for anti-text inside the context.

It should be noted that the step into the "emptiness" holds on the duplicate - the simulacrum, like clutching the straw, and sometimes it jumps away from the author's imaginary requirements, creating the anti-text. Critics of postmodernism (of Lyotard) note that time and place remain decisive in the statements about the world [10, p. 286]. So it is not possible to rip them out of this kind of novel, where every simulacrum makes its existence twice more complicated in the literary style in the shape of stigmatized verbalization.

Here is an example of corporality from the text of "The Greens". The intensifying syndrome of corporality is activated with special attention given to urine and urinating:

"The Milky does not cry; she only urinates... (6, p. 193)

- Can you hear, what a rain, - Kasperavičius will wake us up.

- I can't hear-I'll answer.

- Shush. And I can't hear.

Holding my wrist, he will bring me to the ventilation pipe of an underground hideaway. The candle will illuminate how the drops of rain fall one after another.

- $\quad$ Rain, -I'll confirm. 
- Shush, - Juozas hisses again.

Catching one drop on a finger, he will make you smell.

- Urine, -he will explain.

I will stretch all the remains of my mind and will not be able to explain this phenomenon.

- Rain, -I'll repeat.

- Shush.

Then he puts the barrel of the rifle into the ventilation hole.

- Rain or urine? -He says as if he were betting.

But he will not shoot. He will jump out of the underground hideaway with a rifle.

When we stand before her, and Milky is in front of us, she will say:

- This is for you..." $[6$, p. 179].

- When she died, she smelt of urine, but it was Milky's tears [6, p. 300].

From the perspective of literary scholars defending the author these qualities and ways of expression must justify the language of postmodernism. Howev$\mathrm{er}$, it is the language of anti-Self, significantly hurting the community related to guerilla fighters, the style of cheap corporality like "nothingness" or "emptiness". Literary scholar Rita Ivinskyte in her analysis shows this as a factor of postmodernism. It is "about conditional naming and conditional communication... the uncertainty of the language... The reality, which is established when one person speaks, is never equal to the reality, which... will be perceived by someone else... it is said that an item is named, but not as such... So the language does not allow us to understand reality... inspires duplication. Duplication... destabilises and ridicules discourse" [7, p. 25].

There is also much attention to displacement, to the mismatch between the area and the real name ("Fonteblo" means "Madrid"). "The possibility of dual representation in the novel's reality... shows situations, which in order to concentrate on one particular object of reality, always create non-intersecting meanings" [7, p. 26]. The journalist and producer Liudvika Pociūniene describes the controversial impact of the text's lack of authenticity upon the reader who knows the reality: "In such a context, even one of the historical details taken from the more easily accessible documents seems to be inauthentic. Particularly, a description of a battle in a town, which is somewhat similar to real memories and could inflate life into a sophisticated text, seems to be not in the right place. Reading does not let the feeling of uncertainty go away. Characters are so faceless that the names become confus- ing, and the reader has to go back and check who is who. It cannot be otherwise because the author is not concerned about the motivation of those characters... After turning the last page, the feeling was as if the reader endured a long eye-to-eye confrontation with Frankenstein... So what has to move the "literator's" mind to create this? (The word "literator" is borrowed from the final of the novel - the quote "We are not executioners, we are literators") [17; 6, p. 326]. The national prize in literature should be awarded to the best critics of literature" [16].

\section{Controversial context}

Postmodern simulacrum imagination, "creating of situations", displacement of reality with non-intersectional meanings, which have a highly contradictory twofold fragmentation of "non-reality", is thrown into the still disoriented, post-traumatic, historically damaged medium, where only gradually the contours of real tragedies become apparent. At first, it requires the best possible research. For example, when historians and literary scholars cross their spears about "The Greens", the presentation of historian Arvydas Anušauskas's book "I am Vanagas" (2) is being held at the same time, revealing the new details of the Vanagas (another partisan leader murdered by the Soviets) case, masterfully falsified by the KGB - the mind could not grasp it all. According to the publisher of the book V.V. Landsbergis, the sadistic torture of the partisan commander with scissors was recorded in the file as a "self-injury". The author of the book Dr Anušauskas explains:

"Even after the publication of the book, today new facts come into light about skillfully fabricated Soviet disinformation given to the West about Lithuania, especially to Western leaders, so that Lithuania never gets the help she expected." There is no surprise about having open public response: protests, desire to remind of horrible historical wounds and calls for rejection of such works. The novel "The Greens" is defended by literary scholars, but this brings back the cultural trail of the "fractured time" (the so-called Soviet era) - the darkened shadow culture of discrepancies, controversies, intersections, simulations and bullying. The political scholar and researcher Vidmantas Valiušaitis asks: "Can talent justify the betrayal?" [22]. Thus, the novel "The Greens" acquires its mythological niche in history - as a misunderstanding from all sides: from the criticism as an attempt to tackle the guerilla theme without a full understanding of its complexity, and a strange "revelation" of the Soviet self in the search for the artist's self-expression. The corporality in Post- 
Soviet style is a great help for him in pursuing this purpose.

The problem of the intersection of duality and history is accurately raised by the Polish playwright and film director Krzysztof Zanussi (born in 1939) in his drama "Hybris" about the modern philosopher Zygmunt Baumann (1925-2017), a very famous post-modern humanist, who earlier actively participated in the Stalinist machine of destruction of East European nations, including his motherland Poland [25, p. 23-24].

The theme of displacement in another work, this time not encoded in postmodern and postwar terms, is much more evident in Ivaškevičius' play "Expulsion" (2014), about new immigrants determined to survive in London against all odds, where corporality becomes the key to the drama of survival. The ruthless modern identity of Ivaškevičius's "Expulsion" may become even too aggressive, but it does not face the historical context of partisan warfare, which is still affected by the historical falsifications. Its content does not have to rise at the controversial juncture of the post-Sovietism and postmodernism. Another space - London liberates it.

\section{Example of emptiness in linguistics}

Literary aspect of the intersection is the simulacrum of reality - the duplicate. It brings down the dynamics of history, puts the phrase above time and place as a literary principle without its sources. Therefore, it leaves the words environment without dimension, without sound and implied connections, without interactivity, passive. Here is a quote from "The Greens":

"This field is not over yet, and we need to do something (deactivation - J. L.).

- Do you remember the Count? - I further interrogate Kasperavičius (The image of the Count requires knowledge of true history, at least its clear outlines, which are absent, but the author does not care about this - J. L.).

- Like through the fog.

- And the plane? Was it a bomber?

- What bomber, Jonas. Is "Rumpler C One" for you a bomber? Of course, "Rumpler C" is not a bomber. How could I go wrong? This is "Rumpler C".

- What is this "Rumpler C"?

- "C One", says Jonas and, unless I repeat it, we will never hear about "Rumpler C One".

- "Rumpler C One", - I repeat.

- "C One" is a spy. They made them until the fifteenth year.
- Can you nick it? - I say.

- I'll never get into such a thing.

In fact, it is very doubtful whether it was "Rumpler C" there [6, p. 56].

Without the context and documental explanation the reader experiences the "stigma" of event, where an understanding of the text appears like specific confusing trauma of the "bad phenomenon" of "breathing without air" [16]. In this way the anaemia of the text manifests itself in the work. The text anaemia turns into a critical level of stigmatised reality in contemporary writings as indicated by the philosopher Romualdas Ozolas (1939-2015) who put out the idea of "return to the homeland" as the motif of independence philosophy as late as in 1983 [14, p. 33]. This motif acts as the essence $<\ldots>$ to resist the constant and bothering thought that Lithuania is the "backwaters of the world" [14, p. 34]. On the other hand, it is precisely this that the postmodernism was supposed to resist and correct - the suppression of the minor, the differend, the rejection of context, the elimination of the inspiration in the text.

Speaking about the "fractured time" of the Soviet era in post-Soviet and postmodern expressions, it is necessary to highlight the alternative examples of literature where the images of homeland connect with the completeness of the world, the boundaries of nature and overcome the division of confused society, where author exposes this internal stigma by softening it with the "breathing into the back" of history.

\section{The subtle touch}

The Latvian writer Nora Ikstena (born in 1969) in her novel "Soviet Milk" [5] does not avoid corporality; she deepens it sliding into the eternal, complicated but non-fragmented relationship between mother and daughter. The text below draws out an attempt to expose the passage of time in the Soviet landscape.

"This journey was slow. The lonely stations slowly glided behind the window, followed by the Rumbula forest clearing, where the Jews were shot. I remembered a student party in one of Rumbula's gardens/allotments. Drunk on Vaisiukas (fruit wine), I was looking for a place to sit down. The allotment plot was surrounded by a makeshift fence, held by the weird poles. They were small, overgrown with moss with the nailed crosses on top. Cabbage, beetroot and potatoes will grow lush in this soil for this enclosure of the Soviet people, the soil, which has been fertilised with the human bodies, shot and thrown into the waste pits. The table will be rich; there will be nothing short on it. 
And let the dead be silent, we will raise a glass of drink for them. Pomianem.

This journey was slow. The train rolled into Škiruotava (train depot in Riga). Nothing, absolutely nothing has changed here since the day my daughter and I started my exile. People lived in the same world $<\ldots>$ Nothing could get them reprehended because they were not distributed any more in this Škiruotava. There was no distinction between men and women, husbands and wives, children and parents, grandparents and grandchildren. They were not separated before being taken far away into the cold territories of the Soviet country, where many of them froze to death, died from starvation, where they became slaves of the twentieth century, fertilizing the lands of the vast homeland.

This journey was slow. I was also thinking of a father who was separated here without any scruples. About his hand, which for the last time held my mother's hand, and then it was hit with the rifle stock. And about the mother's hand, which was also hit. About the hands of both of them, which have never met again [5, p. 117].

Here, the fragmentation is overcome by the author's creativity and literary expertise, the internal observation of the "timeline" and the subtle interactions - the game of touching the contextual boundaries. Symbolic testimony of hand-touching like a picture or fixation of the event "without words" reinforces the imaginary of history with a subtle touch of corporality.

Postmodernism in a political context: meta-creation of the present time

In music, similarly, the language of postmodernism can suggest verbal perception of the Soviet era and its fragmented time. Here the reflections of the partisan war are very late - the first piece of music on this subject was composed only in 2018, and was dedicated to the legendary Adolf RamanauskasVanagas (1918-1957), brutally tortured and shot by KGB. The partisan general is now recognized as the legal head of state and buried in 2018 as a president. The piece for flute, cello and organ by Vytautas Germanavičius (born in 1969) is called "The Red Trees" and dedicated to Adolf Ramanauskas-Vanagas. The language of music here illustrates the correlation, interactivity and expressionism of postmodern gestures. They are:

1) "fractured" intonation - an image of fractured time, fulfilled in quartertones, "creeping" sound waves - glissando, scattered rhetorical fragmentation of the phrase, which blends into a single replica of a "cry";

2) "muddled" harmony - illusory "fog" in accords in the choral fusion of verticals, pray and disappearance of the image, using the layering of the sound - the principle of overtone switch-off, connecting the specificity of the organ instrument. It is a deconstruction of destruction and the transcendence of the whole to "another sphere".

3) rhythmic "overbeats" - the arhythmic element, the anti-monotony of pulsation, the beginning of the action in the transformation, the penetration of interactivity not leaving the emptiness - transmitting the fragments into the all-encompassing space.

In music, this meta-language and the "post-war file" coincide, turning into an instrumental drama, which connects gestures and spatiality of musical language, images full of sonoristics, and activating history in a transcendental landscape of sounds. The sound as scenery here "enjoys" its freedom and space, like the very nature without the stigma and danger of totalization.

Meanwhile, the present and the persistence of Lithuania's identity, self-defense of the Self is awake, gets up, speaks with the voices of researchers, young scholars, historians, who, witnessing the facts of history, are committed to reveal the scale of falsifications, hidden codes of Lithuanian statehood, and the continuity of the meaningful line of historicity. The archaeologist of younger generation, Dr Justina Kazokaite, born in 1987, researching the remains of guerilla and rebel leaders describes her work in this way: "After I return to the laboratory and anatomically lay out an unidentified skeleton, already at the first sight the traces of brutal torture and murder are apparent. Bones' remains tell me that here in front of me lies a legend, such as Adolfas Ramanauskas-Vanagas or Konstantinas Kalinauskas (one of the 1863 rebellion leaders, whose bones were excavated at the Gediminas Castle Tower in Vilnius in the fall of 2018, after the slopes of Mount Gediminas started sliding down). At such moments I feel small and do not deserve the greatness which is in front of me" (Justina Kazokaite, speech at a solemn celebration at the Seimas of the Republic of Lithuania, March 11, 2019, www.lrt.lt).

In the present context, after publishing the book "I Am Vanagas" and discovering the remains of Vanagas, it becomes clear what disinformation the Soviets have spread and still release to the West, and why the partisans have not received so greatly anticipated assistance. The concept goes further to the "civil war" 
and people who "still shoot their own". The same was said about the case of January 13th, 1991, so the scale of Soviet disinformation remains endless and contemporarily skilful. In case of "The Greens", the author seems literarily ignorant, with postmodernism modulating here with the motifs of the only one effective and successful factor - corporality, and non-sensual sexuality to compensate the lack of historical genuineness, which should be an apparent spiritual motif here.

\section{Source of renewed dimensionism}

The phenomenon of postmodernism tends to extrapolate from art to other interactions between being and consciousness joining the spheres, where the "incompletely shaped forms of aesthetic existence, which have the ability to spread beyond the united ontical thinking and the perception of reality" are prevalent, according to the Academician Antanas Andrijauskas, researcher in the field of aesthetics and art philosophy [1, p. 42]. "Aesthetics has encountered the problem of coexistence and interaction between the imaginative and true reality" [1, p. 43]. A simulacrum is a phenomenon, which does not have any other form of being, apart perceptive, symbolic, or as per Platonic terminology, is a "copy of the copy" that has no real being [Ibid.]. "Simulacra become the most important motif of virtual aesthetic reality, competing in the consciousness of the perceiver (and the creator! - J. L.) with true reality (and history! - J. L.). Between these two worlds, the boundaries become blurred in the consciousness, they needed the differend..." [1]. "The Greens" as a work of literature encounters precisely this postmodern phenomenon. The simulacrum is compensated here by the factor of corporality and sexuality.

So here are two different realities: literary, in which the simulacra of postmodernism and the relative duplicate of the text - the noncontextuality operate. In his theory, Roland Barthes speaks of the intertextuality of the text formulating original literary concepts, emphasizes the importance of the language in general and the need for every creator to have his/her specific language [1, p. 45]. After Barthes, the most important founder of post-modernism, points out in his aesthetics that the search for meaningful codes is evident; he treated a literary work as a methodological field, which, merging with its criticism, creates a more universal substance covering different areas of culture a contextual text or mega-text [1, p. 47].

Therefore, the critics and/or readers outraged with the context of "The Greens" cannot be dismissed as "illiterate" and wishing to "whiten" or "hero-ise the hero" [12], and vice versa, their texts rightly supplement, reflect, dimensionalize and allow an everyday discourse of mega-text (!) to breathe, covering the actual depth of the problem. An aesthetic collision emerges - non-reality of the simulacra versus the horrible tragedy of reality. It is an impossible interaction.

\section{Documentary context}

A documentary text about the real general Jonas Žemaitis-Vytautas (1909-1953) under a photograph could successfully supplement the context: "1935. Jonas Žemaitis with his sister Kotryna in Palanga on Biruté's Hill. The Soviet occupation broke these people's plans for their glorious future: Kotryna and her family went their "road of suffering" in Siberia, Jonas, who chose to fight until his last breath, was finally arrested and executed by a firing squad" [13, p. 42-50]. Post-Soviet cultural space suffers from an exaggerated phobia of whitening or heroisation (as if in reality in postmodern European society there can be no heroes!), choosing an alternative - the syndrome of grotesque, sometimes vulgar demonization or even bullying. The image of the Lithuanian "sex bomb" Milky recurrent in the text of "The Greens", does not go unnoticed. Why? She (her real name is Nina Nausedaite, but as a guerilla fighter she was called Rasa, 1924-2004) was a courageous medical nurse still living in the memories of her friends from Siberia. She was caught and tortured by KGB, never betrayed her leader Žemaitis, sentenced to many years in a prison camp. Why is she named "Milky" in "The Greens"? Firstly, because of how the author perceived the corporality of a woman - big breasts, and, secondly, because general J. Žemaitis's father was interested and got involved in the development of dairy farming in independent Lithuania. He owned a few dairies (Milky's bullying emerges from here) and wanted his son to choose the same, but Jonas chose warfare. "The future leader of Lithuanian partisans graduated from a military school in Paris around 1931-1934. People, who faced him both in the war field and life, emphasized his strong and withdrawn character, knowledge of the warfare and intelligence; he read a lot, pursued education both in Lithuania and abroad, spoke several languages and fully applied theoretical knowledge in practice" $[13$, p. 45]. This is the image of the current but still fragmented discourse: the philosopher Gintautas Mažeikis talks about the mechanisms of blackening and whitening, excessive heroisation and confusion of artists and researchers caused by the Soviet propaganda, when "a human is already misled and 
get trapped in propaganda virus schemes... When an infected sheet of paper is opened, this virus immediately starts penetrating you" [12].

Meanwhile, historians seek to restore the truth about personalities, including the real heroes, to unblock them from the discourse of Soviet deception and want literature and its texts to find their particular contextual space [8, p. 29]. The conditionality of the text can act as poison in the post-Soviet space, yet not fully recovered from fractured time and contempt for corporality inflicted by totalitarian bacchanalia. Philosopher Jūrate Baranova describes it as the "absurd in absurdity" and reminds us of the thoughts of Sigmund Freud about the lack of writers' responsibility, simply writers' infantilism (3). Hence the text and its inadequacy to reality in the areas where documents become crucial [23] and they are still being destroyed, and the interrogation protocols are still being altered [2]. It reminds one of a painful blackening problem clearing itself with difficulties after the context opens up. However, this problem can be overcome and opened to creative inspiration only by means of context - alive and interactive "body of the text".

\section{Conclusions}

Postmodernism in Lithuanian literature cannot yet find and may not be able to find its adequate stylistic "simulacra carnival" [19, p. 23], the harmony of literary confrontation with the discourse of posttraumatic society. This is evidenced by the longterm scandal, like a pulsing wound, still surrounding Marius Ivaškevičius's novel "The Greens” (2002). It is the story of the post-war partisan commander Jonas Žemaitis-Vytautas (1909-1954) executed in Moscow by the Soviets and recognized as a president by current Lithuania. Today Lithuanian Military Academy is named after him. Here, the writer uses postmodernist methodology of simulacra and duplication resulting in the inappropriateness of the text to the context of reality. According to the philosopher Mažeikis, it provokes the problem of blackening and whitening in Soviet history and "preventing the heroisation" of partisans. However, the effect of "optical error" $[15$, p. 81$]$ ignoring national identity as the source of historical content [20], presenting itself as creativity without boundaries, is produced. Then the writer blocks the very dimension of history,

\section{REFERENCES}

1. Andrijauskas A. Teorinès postmodernizmo išvados ir istoriosofine prasmè [Theoretical Origins of the Postmodernism and Historico-philosophical its meaning and inspirational energy, the deep archetypical sources of nationality, the archetypal layer instrumental in the ongoing breakthrough of the Self. The national Self was well felt by the post-war emigrant writers, who, instead of enjoying the Ego and Shadow, marginalized the history to simulacrum or opened the historical consciousness. Not wishing to trivialise the heroisation of heroes (!), they underplayed by reducing the values of history, depriving it of personality dimension, the value of aristocracy and intellect as pointed out by another contemporary writer Kristina Sabaliauskaite [21, p. 21]. The lack of historicism even diminishes the features of the literary style to the expressions of swearing or pointing to corporality, the "void" coupling of verbal monotony and strange development of anti-self, where the concept of Russian occupation dominates [23], which sounds particularly controversial in the context of the real President of those who perished [4]. Here, it is still the stage of cognitive dissonance in post-war reflections [18], and the aesthetical game could be recognized not as "green" but as "red" [9]. The following points are of special interest:

1) post-modernism and post-Sovietism cause aesthetic "love" and conflict in the junction between different layers;

2) post-Sovietism is a phenomenon of post-traumatic society with opposed directions of discourse; both discourses overlap here, so the "unblocking" is necessary;

3) simulacra of postmodernism double block the real dimension of the history hindered by the Soviets;

4) the case of "The Greens" by Ivaškevičius is special, it can be valuable when coupled with critical context, which transforms the discourse into a relevant and inspiring mega-text;

5) The code of philosophy of art mentioned by the philosopher Romualdas Ozolas remains very relevant. It is the orientation of Lithuanian Self in space which begins in the Soviet period ("The world is here", 1983, 14). A special feature is the rejection of the constantly actual "treason of intellectuals" (24), hybridity (25), "optical error" (15), presenting itself as creativity "without boundaries", which becomes a bullying aesthetic game of postmodernism with the nation's destiny.

Meaning] / Antanas Andrijauskas // Postmodernizmo fenomeno interpretacijos. [Interpretations of Postmodernism Phenomenon] / Ed. and comp. 
Antanas Andrijauskas - Vilnius: Lietuvos kultūros tyrimų institutas, 2009. - P. 23-105.

2. Anušauskas A. Aš esu Vanagas. [I am Vanagas]. / Antanas Anušauskas. - Vilnius: Dominicus Lituanus, 2018. $-272 \mathrm{p}$.

3. Baranova J. Medijos ir ,pažeidžiamų subjektų“ reprezentavimo etika. [The ethics of the representation of media and "vulnerable subjects"]. / Jūratè Baranova - Youtube. Filosofija, INFO 24.01.2019.

4. Gaškaitè-Žemaitienè N. Žuvusiujų prezidentas. Jono Žemaičio biografija [The President of Those Who Perished. A Biography of Jonas Žemaitis] / Nijole Gaškaitè-Žemaitienè - Vilnius: Lietuvos gyventojų genocido ir rezistencijos centras, 2001. $-574 \mathrm{p}$.

5. Ikstena N. Motinos pienas. [Soviet Milk] // Nora Ikstena - Vilnius: Tyto alba, 2019. - 191 p.

6. Ivaškevičius M. Žali. [The Greens] / Marius Ivaškevičius - Vilnius: Tyto alba, 2002. - 327 p.

7. Ivinskytė R. Tikrovè ir jos antrininkai M. Ivaškevičiaus romane „Žali“". [Reality and its duplicates in M. Ivaškevičius's novel "The Greens"] / Rita Ivinskytè - Literatūra ir menas, 08.02.2019, Vol. 3. - P. 24-26.

8. Kazarian S. Neblèstantis aktualumas. [Unfading relevance] / Sima Kazarian - Literatūra ir menas, 08.02.2019, Vol. 3. - P. 27-29.

9. Landsbergis V. Žali žali panemuniai. [Green green shores of Panemunè] / Vytautas Landsbergis - Vilnius: Lietuvos žinios, 08.02.2019. - P. 2.

10. Lechte J. Penkiasdešimt šiuolaikinių pagrindinių mąstytojų. Nuo struktūralizmo iki postmodernizmo [Fifty key contemporary thinkers: from structuralism to post-humanism] / John Lechte - London and New York: Routlege, 2001. - $287 \mathrm{p}$.

11. Lyotard J.-F. The postmodern condition. A report of knowledge / Jean-François Lyotard. Translated by Geoff Bennington. - Minneapolis: Minnesota University Press, $1984 .-110 \mathrm{p}$.

12. Mažeikis G. Herojai ant pjedestalo netenka gyvo dramatiškumo. [Heroes on the pedestal lose their lively dramatism] / Gintautas Mažeikis - www. bernardinai.lt, 21.02.2019.

13. Musteikyte D. Priesaika tèvynei ar - sūnus? [Oath to the homeland or your son?] / Dalia Musteikytè Legendos, 2019, Vol. 1 (36). - P. 42-50.

14. Ozolas R. Pasaulis grịžta namo. [The world returns home]/ Romualdas Ozolas - Vilnius: Valstybingumo Studijų Centras, 2019. - 264 p.
15. Piročkinas A. Optinès klaidos padaras. Ne vien lietuvių kelis rašytojus paveikè bolševikų propaganda. [Creature of optical error. Not only some Lithuanian writers were affected by Bolshevik propaganda] / Arnoldas Piročkinas - Kultūros barai, 2018, Vol. 12. - P. 81-85.

16. Pociūnienè L. Aš dūstu. [I am suffocating] / Liudvika Pociūnienè - www.bernardinai.lt 19.02.2019.

17. Pociūnienè L. Mes ne budeliai, mes literatoriai [We are not executioners, we are literators] / Liudvika Pociūnienè - www.bernardinai.lt 07.02.2019.

18. Pokalbis Mariaus Ivaškevičiaus "Žalių" klausimu. "Kažkas staugè rytuose ir mes sugalvojome klausyti..." [Conversation on the question of "The Greens" by Marius Ivaškevičius. "Someone was howling in the east and we decided to listen"] // Naujasis židinys / Aidai Vol. 2, 2019. - P. 49-59.

19. Ranciere J. The Future of the Image / Jacques Ranciere - London, New York: Verso, 2007. - 180 p.

20. Rubavičius V. Nacionalinis tapatumas, kultūrinè atmintis ir politika. [National identity, cultural memory and politics] / Vytautas Rubavičius Vilnius: Lietuvos kultūros tyrimų institutas, 2019. $-327 \mathrm{p}$.

21. Sabaliauskaite K. Nepatogioji LDK: atminties ir užmaršties karai. [Uncomfortable Grand Dutchy of Lithuania: wars of memory and oblivion] / Kristina Sabaliauskaitè - Vilnius: Naujasis Židinys, Vol. 5, 2018. - P. 27-30.

22. Valiušaitis $\mathrm{V}$. Ar talentu galima pateisinti politinę išdavystę? [Can talent justify political betrayal?] / Vidmantas Valiušaitis - Vilnius: Nepriklausomybès sąsiuviniai, Vol. 4, 2018. - $26 \mathrm{p}$.

23. Valiušaitis V. Istorikai nenaudoja dalies šaltinių. Dr. Augustinas Idzelis ir Lietuvos okupaciju interpretavimo drama. [Historians do not use some sources. Dr Augustinas Idzelis and interpretation drama of occupations of Lithuania] / Vidmantas Valiušaitis - Vilnius: Žara, 2019. - 260 p.

24. Wittig-Marcinkevičiūtė E. Nacionalinès etikos griuvèsiai, arba kaip nužudyti valstybę jos intelektualų rankomis. [The ruins of national ethics, or how to kill the state by the hands of its intellectuals] / Eglè Wittig-Marcinkevičiūtė Vilnius: Kultūros barai, 2013. - 184 p.

25. Zanussi K. Hybris / Krzysztof Zanussi - Warszawa: manuscript, 2012. $-55 \mathrm{p}$. 


\title{
ТІЛО Й ДУША: СУПЕРЕЧНОСТІ ПОСТМОДЕРНІСТСЬКОЇ ЕСТЕТИКИ У ПОСТРАДЯНСЬКОМУ ПРОСТОРІ
}

\author{
Юрате Ландсбергіте-Бехер \\ orcid.org/0000-0003-2356-7264 \\ jurate128@yahoo.de \\ доктор музикознавства,
}

науковий співробітник Відділу музикознавства та театрознавства,

Литовський інститут культурних досліджень

\begin{abstract}
Анотація. У статті обговорюється сучасний дискурс литовської літератури та політичної реальності, з наголосом на естетичних, етичних та історичних конфліктах, які виникають у ньому. Взаємини між постсовєтизмом, де щзе відбивається радянське розуміння імперї та Литви як ї̈ частини, з постмодерністськими симулякрами у романі М. Івашкевічюса «Зелені» (2001) знову привертають увагуу зв 'язку з присудженням авторові Національної премії у галузі літератури за 2018 р. Роман роз'ятрює чимало глибокин ран у сприйнятті повоєнної дійсності. Через спрощчений та волюнтаристський підхід автора до травматичної історї та відсутність у нього дослідницького досвіду виникають болісні суперечності, іншими словами, літературна поверхневість письменника набуває агресивного характеру. Філософ Юрате Баранова згадує з изього приводу думки 3. Фройда щуодо інфантильності письменника як такого. Наразі иее особливо помітно у Литві, коли стає неможливим ігнорувати історію, яка відкривається з останніх знахідок істориків та археологів $і$ з довго приховуваних жахливих свідчень про партизанську війну. Отже, перетин трьох «пост»-постсовєтизму, постмодернізму та наукового дослідження минулого є особливо болісним для багатьох, проте актуальним та неминучим. Такі твори, як роман «Зелені», можна зрозуміти лише в изьому контексті.
\end{abstract}

Ключові слова: постмодернізм, постсовєтизм, симуляиії, дезінформація, контекст, тілесність, анти-текст. 